\title{
Seeking Status, Forging Refuge: U.S. War Resister Migrations to Canada ${ }^{1}$
}

\author{
ALISON MOUNTZ
}

\section{Abstract}

Often people migrate through interstitial zones and categories between state territories, policies, or designations like "immigrant" or "refugee." Where there is no formal protection or legal status, people seek, forge, and find safe haven in other ways, by other means, and by necessity. In this article, I argue that U.S. war resisters to Canada forged safe haven through broadly based social movements. I develop this argument through examination of U.S. war-resister histories, focusing on two generations: U.S. citizens who came during the U.S.-led wars in Vietnam and, more recently, Afghanistan and Iraq. Resisters and activists forged refuge through alternative paths to protection, including the creation of shelter, the pursuit of time-space trajectories that carried people away from war and militarism, the formation of social movements across the Canada-U.S. border, and legal challenges to state policies and practices.

\section{Résumé}

Souvent, les migrants se trouvent dans des zones et catégories interstitielles entre les territoires des États, les politiques publiques et les désignations comme "immigrant" ou «réfugié». Là où il n'existe pas de protection et de statut légal formels, les gens cherchent, forgent et trouvent refuge d'autres façons, par d'autres moyens et par nécessité. Dans cet article, je soutiens que les résistants à la guerre étasuniens au Canada se sont forgé un lieu de refuge à travers de vastes mouvements sociaux. Je développe cet argument en examinant les histoires des résistants à la guerre étasuniens et je me concentre sur deux générations: les citoyens américains venus pendant les guerres menées par les États-Unis au Vietnam et, plus récemment, en Afghanistan et en Irak. Les résistants et les militants se sont forgé un refuge à travers des voies alternatives vers la protection, incluant la création de lieux d'hébergement, la poursuite de trajectoires menant les gens à séloigner de la guerre et du militarisme, la formation de mouvements sociaux par-delà la frontière entre le Canada et les États-Unis et la contestation judiciaire des politiques et pratiques étatiques.

$\mathrm{P}$ eople migrate routinely through interstitial zones and categories between state territories, policies, or technical or legal designations like "migrant" or "refugee." Where there is no formal protection or path to legal status, people seek and forge safe haven in other ways, by other means, and for shorter times than legal status would

Cette œuvre en libre accès fait l'objet d'une licence Creative Commons Attribution-NonCommercial 4.o International License, laquelle autorise l'utilisation, la reproduction et la distribution de l'œuvre sur tout support à des fins non commerciales, pourvu que l'auteur ou les auteurs originaux soient mentionnés et que la publication originale dans Refuge: revue canadienne sur les réfugiés soit citée. 
confer. This article documents this phenomenon through examination of U.S. war-resister migration histories to Canada, focusing on two generations of resisters: people who emigrated during the U.S.-led wars in Vietnam and Iraq. No single causal or "push" factor explains war-resister migration. Like other people, war resisters migrate for diverse reasons. Researching across generations offers opportunities to understand the patterns and divergence in outcomes across their journeys, as well as the distinct policy pathways, legal landscapes, and geopolitical relations through which they entered Canada at different historical moments. Whereas most resisters who migrated to Canada during the Vietnam War found safe haven by immigrating through Canada's new points system, those who came during Iraq made refugee claims and did not-for the most part-find safe haven.

Even where they did not find refuge in legal status, U.S. war-resister migrants forged refuge, even where none was formally available. Resisters and advocates forged refuge through alternative paths to protection, including the creation of shelter, the pursuit of time-space trajectories that carried people away from war and militarism, the location of safe spaces of protection at finer-than-national scales, the formation of social movements across the Canada-U.S. border, and in legal challenges to state policies and practices. Study of such alternatives to formal, legal refugee statuswhich may be temporary-promises to expand understandings and explore alternative forms of protection and also offers the opportunity to centre human agency and politicization in analyses of human displacement and migration in the form of war resistance.

As such, this article shares findings from a research project that explored Canada's role as safe haven for war resisters crossing the border from the United States. These arrivals are about the histories of individuals, households, and communities, but also about shared cross-border histories, and the geopolitical relations between Canada and the United States, which change over time. During the Vietnam War, the Canadian government and society eventually welcomed 50,000 U.S. war resisters, providing safe haven from militarism and a mandatory draft. ${ }^{2}$ A more recent cohort of approximately 300 U.S. resisters began entering Canada in 2004, with 50 among them making refugee claims after service and tours in Iraq and Afghanistan. While some were able to stay and forge alternative forms of refuge informally, all had their formal refugee claims for protection rejected. Nine were deported and served time in military prison. Both groups found and forged spaces of safe haven in Canada, albeit in very different ways. For some, these were paths to citizenship and a new home; for others, shelter was temporary. These are two important historical moments in the relationship between the two countries. The project enhances knowledge and archives, explained below in more detail. While there is a robust literature on resisters from the earlier generation, less literature documents the more recent migration. This project bolsters documentation of both generations and contributes a focus on the resonance and interactions between them.

The research sought to understand meanings of safe haven and to situate these not only in geopolitical histories between Canada and the United States, but also in migration histories of war resisters. Objectives included those to (1) advance knowledge and extend historical records through documentation of resister histories, timely because of the age of the first wave and the recent memory of the younger generation of resisters; (2) increase understanding of meanings of asylum through analysis of the diversity of resisters' experiences of integration and return; (3) probe understandings of U.S.-Canada relations through asylum claims from soldiers; and (4) better understand how war resisters utilize and challenge policies and practices in Canada.

This analysis proceeds with acknowledgment of the complexity of researching Canada as both provider and denier of refuge as a settler colonial state. Exploring the mythology surrounding Canada's reputation as a refuge here unfolds on sovereign territory that dispossessed Indigenous peoples of their traditional sovereign territories. As scholars observe, refugee resettlement is also leveraged to mask geopolitical histories such as Canada's complicity in the Vietnam War. ${ }^{3}$

In the next section of this article I briefly discuss research methods. In the third section I explain the histories and historical context of U.S. war-resister migration to Canada, mapping broad strokes-including parallels and divergent trajectories and geopolitical contexts-across the two generations. In the fourth section I discuss research findings that demonstrate the forging of safe haven as an alternative solution to public policies. The final section offers brief analytical discussion of these findings, outlining key contributions and whether they are applicable in other contexts for thinking about alternative solutions to public policy.

\section{Research Methods}

This research examines the past in order to understand its implications for contemporary immigration and refugee policies and border governance. Methods were designed to better understand and enhance historical records and bring cross-border communities and generations with shared histories into dialogue.

The project's main research question asked what kinds of refuge U.S. war resisters have sought, forged, and been granted or denied access to in Canada. In order to answer this question, two methods were pursued. The first involved archival research on knowledge and data related to the history of U.S. war-resister migration and social movements to 
support this migration to Canada. The second method collected about fifty oral histories with the two generations: with people who resisted conscription into the Vietnam War and those who came during the fifteen years prior to publication. Participants include people who stayed in Canada and those who returned to the Unites States from each cohort, as well as advocates and activists involved in the social movements that supported each generation. Additional methods include analysis of governmental and civil society responses, media coverage, and resister campaign archives, and focus groups where members of both cohorts reflected on meanings of safe haven. While many people observe that the two cohorts are distinct because there was no mandatory conscription for the second, ${ }^{4}$ the research found parallels in their migration histories and experiences of integration, as I will demonstrate. What began as semi-structured interviews with advocates and activists became oral histories. The interconnected nature of advocacy and resistance in this movement meant that it made more sense to pose the same questions in the same way, with conversations about life histories informing the general direction of the oral histories. Many activists were themselves resisters, as many resisters became activists on arriving in Canada. This considerable crossover and shared history meant that oral history proved most appropriate for understanding the life trajectories, world outlooks, and personal experiences that informed participation in social movements and involvement in war resistance.

Oral histories involved discussion of events that unfolded over a long period, with attention to context. Basically "two people sitting and talking about the past," oral histories allowed for a combination of agreed-upon topics and flexibility in the telling. ${ }^{5}$ These particular oral histories explored migration journeys, beginning with circumstances surrounding the decision to migrate, followed by the process of making arrangements and crossing the border. The interview also involved recollections of life in Canada, from early experiences, to applications for status, and decisions rendered. Interviewers and participants explored forms of transition and isolation, community-building and network-formation, and support. The conversations also addressed integration into Canada and eventual return to the United States, including voluntary and involuntary return (or deportation), time in prison, return to community, and interpretations of this migration history. Discussion also explored meanings of Canada as potential safe haven prior to migration, and its meanings as well as participants' forms of self-identification years or decades later.

Approximately fifty oral histories were conducted. While most were done with individuals, some included partners as simultaneous or sequential participants. In a couple of cases, partners were interviewed together; in a couple of other cases divorced partners were interviewed separately (though this was never requested, it was offered and when offered, pursued and important in illuminating gendered relations and disparate experiences of resister migration). Most oral histories were conducted in the private spaces of home, with some in private offices in workplaces or public spaces including cafes, parks, and libraries.

The project's planned methods evolved as field research proceeded, with new opportunities emerging through collaboration with the Toronto-based War Resister Support Campaign (WRSC). As a result of collaboration between researchers and the campaign, three new outcomes emerged. The first involved archiving of the fifteen-year social movement of the WRSC, a collection that will be housed in the Thomas Fischer Special Collections at the University of Toronto, alongside the older archives of the Vietnam-era social movement (also in Toronto and extending across North America). The second unexpected outcome involved creation of an art show, in collaboration with the WRSC and the Just Seeds Collective (a collection of artists working in Mexico, the United States, and Canada on social justice). Framed visual pieces were assembled to narrate the history of the campaign, collaboration with Iraq Veterans against War, and engaging issues related to war resistance more broadly. These were shown at a workshop in Waterloo in 2018. The third project was also exhibited at this workshop: a documentary film that evolved from the research, undertaken as a collaboration between the author and U.S.-based filmmaker Lisa Molomot, and Iraq war resister Corey Glass on second camera. Each offered a new medium through which to more deeply understand, contextualize, and share these histories anew and in interdisciplinary fashion: visually, orally, and affectively in the live telling of one's migration history that can be achieved through film.

\section{Context: U.S. Resister Migration as Search for and Forging of Safe Haven}

From African Americans fleeing slavery, to Loyalist and Indigenous migrations after the American Revolution, to conscientious objectors fleeing participation in the First and Second World Wars, Canada has a long and complicated history as safe haven for people leaving the United States. During the Vietnam War, Canada offered safe haven to resisters fleeing conscription. In 1969 Prime Minister Pierre Trudeau famously remarked, "Canada should be a refuge from militarism." Some 50,000 resisters migrated, with arrivals totalling about 100,000. ${ }^{6}$ Many stayed; others returned.7 More recently, approximately 300 U.S. military personnel arrived as war resisters fleeing tours in Afghanistan and Iraq and seeking refuge in Canada. ${ }^{8} \mathrm{~A}$ few dozen of these made refugee claims, but eventually faced rejection, deportation, and 
imprisonment. ${ }^{9}$ While most people in the earlier cohort found safe haven in Canada in the form of pathways to legal status (becoming permanent residents and citizens), this new generation, generally speaking, with exceptions, did not.

People who fled conscription during the Vietnam War sometimes self-identified or were known popularly as "draft dodgers" or draft evaders, as well as deserters who went AWOL. The former had an easier time entering at the border and acquiring residency because they tended to score more points for higher education. More recent arrivals resisting repeat tours in Iraq and Afghanistan were deemed "deserters" by U.S. authorities, but self-identified as resisters, a framing drawn from the earlier generation. ${ }^{10}$ This shift in perception proved crucial to their reception in Canada and also signals shifting grounds in Canada-U.S. relations and in domestic immigration and refugee policies. Resisters fleeing these different wars entered distinct legal and policy landscapes within Canada. People fleeing conscription in the Vietnam War entered Canada through its newly developed points system, implemented in 1967 as resisters came. They had to prove suitability to Canadian society within the terms measured and defined by the points system (e.g., language, education, work skills). The newer generation entered Canada by making claims for refugee status. Still others in each cohort remained invisible, living underground during each war.

Mandatory conscription of soldiers is often seen as the main difference between cohorts; often overlooked are the influence of geopolitics on asylum-seeking outcomes and distinct forms of violence through which individuals frame claims. Enlistment in the U.S. military is highly racialized and classed. ${ }^{11}$ Many young people join the U.S. military for economic reasons: to support family, secure health insurance, access to higher education, or immigration status. Experiences within the military are also gendered, with gender-based discrimination common. ${ }^{12}$ Recent resister refugee claims were lodged in Canada for various reasons, among them lack of access to conscientious objection and different experiences of violence within the military. No single explanation encapsulates any war resister movement, and therefore this project took an intersectional approach to tease out the complexity of war resistance.

Researchers have documented important dimensions of the earlier migration of an estimated 50,000 (documented) to 100,000 (documented and undocumented) U.S. resisters searching safe haven in Canada. ${ }^{13}$ These histories focused on early experiences of flight, arrival, resistance, and integration, as well as social movements that were founded by resisters to support resisters. ${ }^{14}$ Some early resisters went to rural locations, forming collectives on geographical margins of Canadian society, such as small island communities and remote interior towns of British Columbia. ${ }^{15}$ Others went to
Canadian cities such as Vancouver and Toronto, the latter identified by Hagan (2001, ) as the "eye of the storm of the Canadian resistance."

A handful of Iraq war resisters based in Toronto became vocal spokespeople in mainstream and social media about resistance. Among these was Jeremy Hinzman, the first among this cohort to arrive in Canada and file a refugee claim in 2004, after a tour in Afghanistan. Hinzman spent three years in the U.S. army, applying twice for Conscientious Objector Status-his request denied both times. Canada's Immigration and Refugee Board (IRB) rejected his claim. Hinzman pursued appeals and status on "humanitarian and compassionate grounds." While ordered to leave in 2008, he appealed and won the right to stay in 2009. In contrast, another resister and refugee claimant, veteran and conscientious objector Joshua Key, was granted support on appeal by ruling of the Federal Court that the IRB reconsider his refugee claim on the basis of the requirement that he systematically violated Geneva Conventions during his service in Iraq. ${ }^{16}$ Brandon Hughey became the second resister to seek asylum that same year. He also had his claim rejected but, like Hinzman and Key, was allowed to stay on humanitarian and compassionate grounds.

Other soldiers made claims of identity-based persecution. For example, nineteen-year-old lesbian Bethany Smith fled homophobic threats to her personal safety on base in Fort Campbell, Kentucky, and arrived in Canada in 2007.17 In 2009, a Federal Court ordered Canada's IRB to reconsider her case because it was not only a claim from a conscientious objector. According to Judge Yves de Montigny, "At the heart of the applicant's claim is that she is a lesbian member of the U.S. army, who was harassed and threatened at the same base where a gay member of the army was beaten to death, and who feels she could not rely on her superiors to secure protection. She fears that she could be punished for leaving an environment that could not secure her protection."18

While Hinzman, Key, Hughey, and Smith were allowed to stay, most others were not. Robin Long was the first resister deported from BC in 2008, sentenced to fifteen months as prisoner of conscience. ${ }^{19}$ Cliff Cornell was deported and sentenced to twelve months in military prison. In 2012, Kimberly Rivera was the first woman among the cohort arrested when she returned to New York State and was sentenced to ten months in military prison. ${ }^{20}$ Rivera was pregnant at the time of deportation, gave birth to her third child, and was separated from her children while serving time.

The War Resisters Support Campaign was founded in Toronto in 2004, approximately two years after military action began in Afghanistan and four decades after the earlier campaign was founded in the same city. ${ }^{21}$ The campaign ended in 2019 when the last of fifteen resisters received 
permanent residency in Canada. The campaign garnered public support, lobbied the federal government for status, and publicized histories. Canadian citizens submitted over 95,00o telephone calls and postcards to parliamentarians in support of granting legal status to resisters. ${ }^{22}$ In 2007 Parliament's Standing Committee on Citizenship and Immigration moved that U.S. war resisters and immediate family be granted the right to stay. ${ }^{23}$ With 64 per cent of the Canadian public in favour of allowing resisters to stay, the House of Commons passed a non-binding motion (by vote of 137 to 110) directing the government to stop deportation proceedings and allow them to remain. ${ }^{24}$ Although resisters enjoyed majority support, the minority government did not enact the legislation, and deportation orders were issued. ${ }^{25}$ The campaign continued for nearly fifteen years, fuelled by appeals, court decisions, the release of Wikileaks documents about motivations for U.S. military action in Iraq, deportation orders, and renewed attempts by U.S. war resisters to make refugee claims in 2014.

While individual journeys and their outcomes differed across cohorts, there are also parallels, from the challenge of acquiring conscientious objector status and the decision to enter Canada, to formation of resistance campaigns in Toronto. There also is variety in individual decisions to migrate, including racialized, classed, sexualized, and gendered experiences of crossing, immigration, and settlement in Canada and return to the United States.

Although claimant systems are meant to provide a fair hearing for individuals, research shows that geopolitics shape mobility, asylum claims, and outcomes, and hearings are not always "fair." 26 During the Cold War, for example, asylum claimants from communist governments found higher rates of acceptance in the United States. ${ }^{27}$ The earlier generation of resisters arrived at a time when the United States and Canada diverged more in foreign policy, with prolonged U.S. involvement in Vietnam causing domestic turmoil. Canada eventually welcomed those who opted out. Under recent administrations, the two countries aligned more closely in foreign policy and immigration and refugee policies, especially with intensified border securitization following terrorist attacks on 9/11. Canadian forces participated in Afghanistan, but not Iraq, in response to mass opposition to the war in Iraq across Canada. For many reasons, Canada would not send a message to the United States that its military personnel were in need of protection, shifting Canadian foreign policy among them. When a claimant finds acceptance or rejection, that decision reflects the credibility of the individual story as well as national priorities and geopolitics between countries.

Additionally, since the 1990s, public discourse about asylum seekers has gradually eroded public belief in the notion of "authentic" claims that fit the 1951 convention, replacing them in public discourse with terms like "bogus refugee." 28 In 2009 Minister of Immigration Jason Kenney referred to U.S. war resisters as "bogus refugee claimants."29 In 2010 Citizenship and Immigration Canada released Operational Bulletin 202, which instructed Canadian immigration officers processing cases involving deserters to refer them to senior advisors. This raised concerns that the government was criminalizing resisters and exercising discretion in handling their cases more centrally. ${ }^{30}$

The decision to leave home and seek asylum involves not only ethical, legal, and political struggle, but complex emotional terrain, as participants' oral histories demonstrate. Consideration of the violence of militarism and meanings of safe haven must attend to emotional geographies, a burgeoning field that informs this analysis. As Divya Tolya-Kelly notes, "The field of 'emotional geographies' is the location of the recovery work that embraces embodied experience ... and the political materialities that resonate from and that are formed through emotions." ${ }^{11}$ Having discussed briefly in this section the shifting geo-political and policy contexts, in the next section I engage in this embodied "recovery work" with resisters. Their histories offer the possibility of expanding understandings of safe haven as a collective, non-state, organized response to violence, trauma, and resistance to war.

\section{Forging Safe Haven Where Legal Paths Remain Unclear or Unavailable}

While the earlier cohort generally found safe haven in Canada as a legal form of belonging, this new generation did not (with exceptions). Although largely denied legal status, evidence shows that members of both cohorts did collectively find and forge safe havens beyond legal status, such as accommodation, refuge in churches, and campaign meetings. ${ }^{32}$ I distinguish the notion of forging refuge from more formal policies of protection (through refugee resettlement and private sponsorship) and sanctuary. Well-documented histories of sanctuary across North America ${ }^{33}$ involve formal decisions by institutions such as churches or municipalities to act as a safe haven by formally not cooperating with federal enforcement authorities. This section outlines four ways in which U.S. war resisters forged safe haven where legal paths to more formal and lasting forms of protection, such as legal status, remained unclear, uncertain, or unavailable.

\section{Forging Safe Haven through Collective, Cross-Border Social Movements}

Both cohorts of resisters joined forces with other members of civil society, in many cases founding and leading collective, cross-border social movements and their campaigns. Faithbased institutions provided sanctuary and pressured governments to accept resisters. So too did other non-governmental 
organizations. Hagan documents the important role of the Toronto Anti-Draft Programme (TADP) in providing information and counselling to potential draft resisters before they left the United States and once they arrived in Canada. This was accomplished through a vast transnational movement of young people working across Canada and the United States to train draft counsellors and distribute information on how to avoid the draft and how to emigrate to Canada. In our archival research, we reviewed materials used by draft counsellors and saw the geographical reach of distribution of the Manual for Draft-Age Immigrants to Canada, recorded in logs of mailings of the manual to churches and university campuses across the United States. ${ }^{34}$ Many participants who secured the book explained how important it was to their knowledge and decision-making.

The contemporary War Resister Support Campaign drew on the political and logistical strategies of the earlier campaign by TADP and other organizations across Canada. The newer campaign emerged through cross-border protests and alliances and conversations with Iraq veteran families against war and activists in Toronto. When the first resisters arrived and made claims in Toronto in 2004 and 2005, activists were catalyzed to build on these early connections and conversations to organize. While initiated by a broad-based swath of civil society (e.g., steelworkers, unions, feminists, peace activists, and faith-based groups), their first serious push for outreach to build membership was to invite Vietnam-era resisters to join them. These earlier resisters joined at the first meeting and became the heart of the campaign. They were able to share personal histories and political strategies, carrying living memory into the new movement. The new campaign studied the archives and tactics of their earlier counterparts, whilst joining forces with them. They also provided connection, understanding, and social acceptance of resisters.

Lee Zaslosky was one such Vietnam-era resister from New York City. 35 Lee was drafted into the Army and served time in basic training, but fled to Canada before deployment to Vietnam. Lee decided he would set about becoming Canadian as soon as he arrived in Toronto and built a political career organizing in Canada. He was invited to attend the first meeting of the campaign and eventually worked part time for the campaign. During this time, he answered phones, helped potential resisters to learn about Canada, and welcomed them when they arrived at the bus station downtown. One of Lee's many contributions to the campaign was his identification with the new cohort of resisters and his firm commitment to demonstrate care for and acceptance of them as soldiers in exile and potential future Canadian citizens. As Lee explained in his oral history, when he met new arrivals at the bus station, he hugged them, welcomed them to Canada, and told them, "I love you, because you're a war resister like me." In turn, several
Iraq-era resisters interviewed narrated their phone conversations and live encounters with the campaign as embodied by conversations and encounters with Lee.

Resisters from both generations found common cause and forged community in the War Resister Support Campaign. Weekly meetings at Steelworkers Hall in downtown Toronto were followed routinely by drinks at Grossman's Tavern on nearby Spadina Avenue. Grossman's was popular among resisters whose community was centred in Toronto's Kensington Market during the height of Vietnam War-era resistance in the 1960s and 1970s. Grossman's was but one of several experiences shared by the two generations.

As the fifteen-year campaign went on, resisters made personal decisions for themselves and families, and they made different decisions-to stay, leave, resist, face imprisonment, or go underground. But before and during their time in Canada, and in several cases once they returned to the United States, they were able to support one another. They forged safe haven through interpersonal relations and collective work with the campaign.

Most resisters interviewed knew little about Canada, and most had never visited Canada prior to arriving. For those arriving as deserters opposing wars in Iraq and Afghanistan, participation in the campaign and early encounters even over the phone offered social networks and-importantlyacceptance. This involved not only engagement with the campaign in Toronto, but assistance from US-based Vietnam War veterans offering to help deserters leave the military by assisting with travel to Canada.

\section{Forging Safe Haven by Providing Shelter in Collaboration with Civil Society}

Broadly based participation of civil society in resister support campaigns within Canada meant that resisters were immediately exposed to, supported by, and sheltered with many different kinds of people in Canada. For Dean Walcott, who had done two tours in Iraq and a third in Germany, where he developed debilitating PTSD, the safe haven he found in the campaign began with telephone calls to campaign headquarters. Lee answered his call and spoke with him several times about the history of resister migration to Canada, recommending reading that might help him to better understand this history as he went through his own decision-making about whether, when, and how to cross. As Dean explained, "It was like I found a home over the phone." Even this early exposure to people who thought like him affirmed to him for the first time that he was "not alone," "not so crazy," and that there was the possibility of a home for him somewhere beyond the United States. Dean's exposure to home through the campaign moved from being something abstract (telephone conversations with people he had not yet 
met) to something more material. When he first arrived, the campaign had arranged for Dean to stay in an extra room in the home of university faculty in Toronto.

As campaign organizers explained during their oral histories, a key function of the campaign was to find housing when resisters arrived. A housing committee was devoted to finding space. New arrivals like Dean would stay with families who volunteered shelter in their homes, until longerterm accommodation could be secured. Brandon Hughey described the first night that he spent sleeping safely in a spare bedroom of a family in St. Catharines, a city near the border, on the night of his crossing as a time of relief and "one of the most memorable days of my life."

Resisters also worked together with campaign volunteers to provide shelter for one another. Franklin's role in sheltering new arrivals is instructive. Franklin joined the U.S. National Guard in 2003 and in 2005 was notified of his deployment to support Operation Iraqi Freedom. During his two years of enlistment and deployment, he grew disenchanted with his role in the military, tired of balancing full-time military service, school, and work, and skeptical of the U.S. role in the conflict. During his time in Iraq, Franklin witnessed violence and corruption and spent his time retreating from it. He was eventually placed in the Green Zone and tasked with supervising others. During this time, he eventually decided to lay down his weapon. Once he communicated that, he was sent on ten-day leave, during which time he fled to Canada.

Once in Canada, Franklin became a leader among peers and very involved in the campaign. After securing his housing with a local landlord sympathetic to resisters, he divided his apartment to make space for new arrivals. Every piece of living space was accounted for, including converting the kitchen to a bedroom. Eventually he secured a second small apartment and carved that one up too, so that resisters could function more independently and also contribute to the work of the campaign as they forged community together. Franklin also helped peers to find work, and together they established a set of sympathetic employers willing to hire resisters, at nightclubs in particular. Franklin worked for two years collecting bodies after deaths all over the GTA, but lost his job after his efforts to unionize workers. He then worked at a nightclub as custodian, eventually employing other resisters. During his twelve-year struggle to secure legal status, Franklin appealed and somehow managed to outlast three deportation orders and a prolonged legal battle until there was a change in government. Now with status, he remains a leader, routinely fielding calls and reporting to others when one seems adrift, whether struggling with mental health or homeless and in need of work and shelter.

While still struggling for legal status and leading precarious lives, like their predecessors, Iraq war resisters supported one another in material and emotional ways in pursuit of shelter, livelihood, and education. The recent campaign created a short version of the Manual, updating its services, assisting with legal bureaucratic requirements, and finding work and housing.

\section{Forging Provisional Safe Haven through Time and Space Away from War, Militarism, and Imprisonment}

Even when resisters returned to the United States- forcibly or by choice-they returned prepared with new resources: moral support, time spent in healing and exploring legal options, a transnational community, attention of the activist community to their continued plight post-return, and support of peace communities and Iraq veterans against war. This support extended to legal support to stay out of prison and to survive once imprisoned (through letters and visits, for example). Time in Canada, however short, offered opportunities to heal from the physical and emotional stress of military service and the violence of war.

Robin Long was the first Iraq War resister deported in 2008, after entering Canada in 2005 and lodging a refugee claim for protection in Ontario. Long was raised Mormon in Boise, Idaho, but forced from home when he decided to leave the church at sixteen. He then hitchhiked, eventually landing in a job corps program in the U.S. South. When he scored well on aptitude tests there, he was approached by military recruiters and offered a signing bonus for enlistment worth us $\$ 12,000$. During his time in training, the Iraq war unfolded. Robin trained to repair tanks and spent much of his time in training to prepare troops for ground combat in Iraq. He was frequently assigned to play the enemy and eventually began to identify with Iraqi civilians and question the motives behind U.S. war-making in Iraq. Alone with these thoughts, Long became suicidal and as punishment for his mental health crisis was assigned rapid deployment to Iraq. He had ten days to say goodbye to friends and family before deployment to Iraq on his own (not with his company), assigned to a depleted company in Fallujah. Long had been in the army for two years. On the day that he was scheduled to fly to Iraq, he reported to the airport, boarded the plane, then deplaned and went into hiding. Eventually, Long fled to Canada.

In his oral history, Robin spoke emotionally of the community and acceptance he found among a traveling band of environmentalists who were making a documentary about waste. He encountered this group shortly after entering Canada in Saskatchewan and traveling to Nelson, BC. He travelled with them from coast to coast. He recounts this time and his friends fondly, explaining that they listened to his stories, accepted him and his history, and met his needs for food, shelter, and healing, after surviving a traumatic period of mental health duress and attempted suicide while on base. 
During his time in Canada, Long fell in love with Canada, found support and community with whom he could share his story. He partnered with a Canadian woman with whom he had a son. Eventually, his refugee claim and subsequent appeals and efforts to remain in Canada failed. He was the first resister deported to the United States in 2008, handed over to U.S. authorities for punishment. After deportation from Canada, he was banned from re-entry for ten years, forced to witness his son's growth from afar, with occasional visits to the United States. After his high-profile military court trial in Colorado, Long received a felony conviction and spent one year and four days imprisoned in a naval brig in San Diego. Although most people are not prosecuted for deserting the U.S. military, it is believed that these resisters were punished more harshly than most because they had spoken out during their time in Canada. ${ }^{36}$

Robin's time in Canada enabled him to forge refuge through community formation in his cross-country trip, including the ability to share truths and not hide his history. As he describes that first summer in Canada, "It was an amazing summer that brought back my humanity.... That summer saved my life." He found support and understanding among people in Canada. "In Canada, you could just be completely free and open, and people seemed to understand you." Even though he was deported three years after he had arrived, Robin carried these healing experiences back with him. Robin believes that his time in Canada prepared him by allowing to heal and find strength needed to recover and then survive the trial, time in prison, and family separation.

Like Robin, many people were fleeing not only the stress of war, but the stress and violence of time in the military. Participants described this time as oppressive, suffocating, and stressful, with one likening his time after being drafted into the army during the Vietnam War to doing time in prison.

Iraq war resisters explained the mental health struggles that they themselves survived, and the mental health crises they witnessed among other soldiers. These narratives featured PTSD, suicidal ideation and attempts, and periods of severe depression and anxiety. Some resisters who came to Canada had such severe PTSD that they had trouble leaving their homes and therefore securing work or pursuing refugee claims.

While much has been written of the trauma caused by war and its long afterlife, less has been written about cultures of militarism within the military and among war resisters. ${ }^{37} \mathrm{~A}$ key finding of this study, made possible by comparing two generations, is that resisters much later in life still experience the trauma of conscription, enlistment, desertion, and flight, as though it happened yesterday. These histories settle in and haunt lived daily experience as acute forms of anxiety and fear. One deserter explained that even nearly fifty years later, these worries and fears still repeat in his mind "like a tape, like a monkey on my back." He moved several times to get farther away from the Canada-U.S. border, but still remembers as though it was yesterday and struggles with acute anxiety.

One Iraq-era resister ultimately forced to return to the United States explained, "People don't just have post-traumatic stress disorder from war. They have post-traumatic stress disorder from the platoon.... How can you go to war and see the atrocities of war, and then return back to your platoon and face abuse? How can a person handle that?" Linjamin was trained as a social worker and a careful observer of people around him. During his first month in basic training with the army, a fellow soldier in his platoon attempted suicide. As a social worker, Linjamin felt he had a duty to report his fellow soldier's duress. As a result of reporting, however, he was discharged from the army, punished for his decision to challenge conformity and silence. He eventually re-enlisted after a period of homelessness and living in and out of shelters in New York City. After re-enlisting, he stayed for a longer period of time in the military. However, he never wanted to go to war in Iraq and knew that he was about to be deployed. Linjamin entered the military for economic survival but never wanted his own economic survival to come at the expense of someone else's in another country where he felt he had "no business." Like the others, Linjamin's claim for refugee status failed. However, his time in Canada allowed him to develop his own identity and paths to livelihood outside of the U.S. military. As he describes his stability in Canada, "It was socially the most stable I have probably been in my whole life." Linjamin recounted invitations to stay in people's homes and visit for dinner at homes in London and Toronto, where they asked about his past, listened to his stories, and affirmed and supported his decision to emigrate. This time enabled Linjamin to prepare for the new life that he would build once he returned to the United States, where he returned to pursue higher education.

\section{Legal Strategies and Challenges}

Accompanying the day-to-day logistical dimensions of forging safe haven discussed thus far (participation in social movements, shelter, and healing space away from militarism and the violence of war), resisters and the campaign simultaneously pursued legal strategies to forge and extend safe haven. Even when these strategies failed in the courts or failed to secure legal status, they extended resisters' time in Canada and involved the international community in testing the Canadian government's legal boundaries for safe haven. In this sense, pursuit of legal strategies mirrored diverse efforts to provide sanctuary for asylum seekers. ${ }^{38}$ Many of these legal manoeuvres related to testing Canada's 
implementation of its commitments to the 1951 Convention Relating to the Status of Refugees, and the status of claims based on war resistance therein. Jeff House and Alyssa Manning were Toronto-based refugee lawyers who worked with the campaign and represented most resisters, developing new legal strategies with each failed claim.

As Hagan demonstrates with the use of the points system to reduce discrimination toward Vietnam-era deserters by immigration bureaucrats, the legal strategies designed for the new generation were developed to combat the landscape in which U.S. soldiers seeking protection received negative decisions from the IRB. Whereas the IRB process tended to not see these applicants as demonstrating a well-founded fear of persecution for membership in a social group, subsequent appeals tested alternative arguments. These included participation in an illegal war in Iraq and the requirement that soldiers violate Geneva Conventions while there.

In addition to the development of legal arguments, the appeals and court cases also provisionally extended time forged for safe haven away from punishment to be meted out when resisters were deported back to the United States. As Brandon Hughey explained, resolving his legal case took more than ten years but was well worth this time, for the opportunity it afforded him to find safe haven, and when he eventually secured legal status. For the fifteen resisters who were eventually granted legal status, the change in government from Conservative to Liberal drew the end of their waiting game nearer, as they had persuaded the Liberal government to commit to supporting their hopes for legal status as Justin Trudeau campaigned to become prime minister.

\section{Conclusions}

This article discussed two generations of U.S. war-resister migrations to Canada in order to explore alternative, often informal ways of forging safe haven where paths to legal status are absent or limited. Resisters and activists worked collectively as members of civil society to forge refuge, motivated by solidarity, belief in peace, opposition to war, contestation of public policies, and a belief that historical cycles will recur and test Canada's potential as safe haven in the future.

Juxtaposition of two generations proximate in time and space offers opportunities to better understand the resonance across their journeys, as well as the distinct landscapes they entered in Canada. Even where U.S. resisters did not find formal refuge, they forged refuge collectively with other members of civil society-even if temporary. This forging involved alternative paths to protection, including shelter, pursuit of time-space trajectories that carried people away from war and militarism, location of safe spaces of protection at finer-than-national scales, formation of social movements across the Canada-U.S. border, and legal challenges to exclusionary state policies and practices. Study of such alternatives to formal, legal refugee status can expand understandings of protection and also centre human agency and politicization in analyses of human displacement and migration.

Even pursuit of legal challenges and status at times involved formal processes set in motion for goals alternative to those for which they were designed. Status acquired through the points system and on humanitarian and compassionate grounds, for example, allowed formal forging of safe haven through policies not originally developed to respond to or account for war resisters.

The resisters' searches for safe haven are similar to and different from other forms of displacement and migration. Nonetheless, this analysis is applicable and can be extended to other contexts and alternative understandings of solutions. Research remains to be done, including more work on other alternative solutions to formal provisions of refuge. While a particular set of migrations in a particular location, these lessons can be applied and are readily apparent in other contexts. Recent reporting, for example, examined the highly organized democratic governance structures of the caravans of Central American asylum seekers moving through Mexico to the border with the United States and the forging of safe haven, however temporary, within those moving structures. ${ }^{39}$ Much scholarship examines unauthorized migration where people move through interstitial zones, jurisdictions, and categories between state territories, policies, or designations-like migrant or refugee. As I have shown, occupation of these zones between legal categories and territories proves fertile ground and the need for collective practices and movements to forge safe haven where there may be no legal pathways. Where there is no formal refuge or legal status, people seek, forge, and find safe haven in other ways, by other means.

\section{Notes}

1 This research was funded by Insight and Connection grants from the Social Sciences and Humanities Canada. I thank Jennifer Hyndman and Joanna Reynolds for their work in organizing the excellent workshop that gave rise to these articles. I'm grateful for collaborations with resisters, the War Resister Support Campaign, Just Seeds Collective, filmmaker Lisa Molomot, and geographers Shiva Mohan, Ileana Díaz, and Jacque Micieli-Voutsinas. Any errors rest with the author.

2 John Hagan, Northern Passage: American Vietnam War Resisters in Canada (Cambridge, MA: Harvard University Press, 2001). As Hagan notes, these estimates varied widely. While it is believed that more than 100,000 people 
migrated temporarily during this time, the census records approximately 50,000 who regularized their status and remained in Canada after the war ended.

3 Anh Ngo, "Journey to Freedom Day Act': The Making of the Vietnamese Subject in Canada and the Erasure of the Vietnam War," Canadian Review of Social Policy 75 (2016): 59-86.

4 Sarah Hipworth and Luke Stewart, eds., Let Them Stay: U.S. War Resisters in Canada 2004-2016 (Toronto: Iguana Books, 2016), 2.

5 Rebecca Sharpless, "The History of Oral History," in Thomas Charlton, Lois Myers, and Rebecca Sharpless, eds., The Handbook of Oral History (Lanham, MD: AltaMira, 2006), 38.

6 Susan Hardwick and Ginger Mansfield, "Discourse, Identity, and 'Homeland as Other' at the Borderlands," Annals of the Association of American Geographers 99, no. 2 (2009): 391.

7 Hagan, Northern Passage, 3.

8 This figure is a conservative estimate based on communications between resisters and the War Resister Support Campaign over the course of the campaign.

9 Wil S. Hylton, "American Deserter: Why awol U.S. Soldiers Are Most at Risk in Canada," New York Magazine, February 23, 2015.

10 New York Times, "War Dodgers," March, 23, 2008.

11 Associated Press, "Military Makes Little Effort to Punish Deserters: Although Numbers Rising, Only 5 Percent of Lawbreakers Reprimanded," June 28, 2007, http://www. nbcnews.com/id/19489285/ns/us_news-military/t/military-makes-little-effort-punish-deserters/\#.VCwhQWBLo9Q; Amy Lutz, "Who Joins the Military? A Look at Race, Class, and Immigration Status," Journal of Political and Military Sociology 36, no. 2 (2008): 167-88.

12 Jennifer Boldry, Wendy Wood, and Deborah Kashy, "Gender Stereotypes and the Evaluation of Men and Women in Military Training," Journal of Social Issues 57, no. 4 (2002): 689-705. Sara Corbett, “The Women's War," New York Times, March 18, 2007, http://www.nytimes.com/2007/03/18/ magazine $/ 18$ cover.html?pagewanted $=$ all\&_r $=0$.

13 Hardwick and Mansfield, "Discourse, Identity and 'Homeland as Other"' 391.

14 Alan Haig-Brown, Hell No We Won't Go: Vietnam Draft Resisters in Canada (Vancouver: Raincoast Book Distribution, 1996); Renee G. Kasinsky, Refugees from Militarism: Draft-Age Americans in Canada (New Brunswick: Transaction Books, 1976); Jessica Squires, Building Sanctuary: The Movement to Support Vietnam War Resisters in Canada, 1965-1973 (Vancouver: UBC Press, 2013).

15 Hardwick and Mansfield, "Discourse, Identity and 'Homeland as Other."

16 Joshua Key and Lawrence Hill, The Deserter's Tale: The Story of an Ordinary Solder Who Walked Away from the War in Iraq (as Told by Lawrence Hill) (Toronto: Anansi, 2007).

17 Toronto Star, "Gay U.S. Soldier Gets Second Shot at Refugee Claim," 21 November 21, 2009.
18 Toronto Star, "Gay U.S. Soldier Gets Second Shot."

19 War Resister Support Campaign, 2014, http://www.resisters.ca/index_en.html.

20 Associated Press and Canadian Press, "U.S. Soldier Who Fled to Canada to Avoid Iraq War Gets 10 Months in Jail," April 29, 2013, https://www.macleans.ca/news/u-s-soldierwho-fled-to-canada-to-avoid-iraq-war-gets-10-monthsin-jail/.

21 Hagan, Northern Passage.

22 War Resisters Support Campaign, 2014.

23 War Resisters Support Campaign, 2014.

24 War Resisters Support Campaign, 2014.

25 War Resisters Support Campaign, 2014.

26 Jennifer Hyndman, "The Geopolitics of Migration and Mobility," Geopolitics 17, no. 2 (2012): 243-55.

27 Carl Bon Tempo, Americans at the Gate: The United States and Refugees during the Cold War (Princeton: Princeton University Press, 2008).

28 Sean Hier and Joshua Greenberg, "Constructing a Discursive Crisis: Risk, Problematization and Illegal Chinese in Canada," Ethnic and Racial Studies 25, no. 3 (2002): 490-513; Audrey Macklin, "Disappearing Refugees: Reflections on the Canada-U.S. Safe Third Country Agreement," Columbia Human Rights Law Review 36 (2005): 365-426.

29 War Resister Support Campaign, 2014.

30 Hipworth and Stewart, Let Them Stay, 226-43.

31 Divya Tolya-Kelly, "Affect: An Ethnocentric Encounter? Exploring the 'Universalist' Imperatives of Emotional/ Affectual Geographies," Area 38, no. 2 (2006): 213-17.

32 Hier and Greenberg, "Constructing a Discursive Crisis": Macklin, "Disappearing Refugees."

War Resister Support Campaign, 2014.

33 Randy Lippert and Sean Rehaag, eds., Sanctuary Practices in International Perspectives: Migration, Citizenship and Social Movements (New York: Routledge, 2012); Graham Hudson, Idil Atak, and Charity-Ann Hannan, "(No) Access то: A Pilot Study on Sanctuary City Policy in Toronto, Canada," Ryerson Centre for Immigration and Settlement Working Paper Series 1 (2017).

34 Mark Satin, Manual for Draft Age Immigrants to Canada (Toronto: House of Anansi, 2017).

35 Full name indicate participants who chose to be named in this research, whereas use of first names only indicate pseudonyms used to protect identities.

36 Hipworth and Stewart, Let Them Stay.

37 Pamela Moss, "Shifting from Nervous to Normal through Love Machines: Battle Exhaustion, Military Psychiatrists and Emotionally Traumatized Soldiers in World War II," Emotion, Space and Society 10 (2014): 63-70; D. Cowen, Military Workfare: The Soldier and Social Citizenship in Canada (Toronto: University of Toronto Press, 2008); Deb Cowen and Emily Gilbert, eds., War, Citizenship, Territory (New York: Routledge, 2008).

38 Lippert and Rehaag, Sanctuary Practices in International Perspectives. 
39 Jesús Rodriguez, "How the Migrant Caravan Built Its Own Democracy," Politico, December 12, 2018, https://www.politico.com/magazine/story/2018/12/12/ migrant-caravan-tijuana-border-government-222856.
Alison Mountz is professor and Canada Research Chair in Global Migration at Wilfrid Laurier University. She can be reached at amountz@wlu.ca. 